\title{
A Quantitative Analysis of Postgraduate Programmes Admission of the Hong Kong Institute of Education
}

\author{
Qing-Yun Li \\ Department of Computing, The Hong Kong Polytechnic University, Hong Kong \\ Email: qy.li@connect.polyu.hk
}

\begin{abstract}
This paper analyzed 8 years' student admission trend of Hong Kong Institute of Education (HKIEd) postgraduate programmes in 2 time slots. In the first time period, year 2007-2010, we use the waterfall and competing pattern model for the quantitative analysis of the postgraduate programmes in a holistic manner of HKIEd, and further study the general student admission trend of year 2011-2013, due to the sharp increase of mainland China students and the 3-3-4 Scheme Education System Reform in 2011 and 2012. In this paper, we utilize this rich collection of programmes to identify usable admission patterns by analyzing admission data of the past years for reinforcing the institute's strength and reputation, whose programme spectrum was expanded and enhanced quite drastically since 2005 with the introduction of 1 st Master in Education cohort. In particular, this paper is focused to locate: 1) if there is any internal competition and how severe the competition is. 2) If there is any programme that can be utilized as strategic recruitment? and 3) the general student admission trend of the 8 years. With this study, management can better understand where the sources of applicants come from. New insight can be drawn and new strategy can be defined to recruit more quality students which are also aligned with our strategic move to transform the students. The methods used in this paper can be easily applied in other University for analyzing the admission issues, and can demonstrate to management how operation data can be utilized to form valuable insights and significant improvement can then be made based on these identified facts.
\end{abstract}

Index Terms-General trend, holistic manner, postgraduate programmes, quantitatively analyze, strategic recruitment.

\section{INTRODUCTION}

HKIEd is a teacher education focused institute. Graduates of the Institute's teacher education programmes are eligible to become fully qualified and registered teachers. Besides the Institute, there are other tertiary Institutes offering teacher education programmes. Today, the Institutes holds the largest market share; $84 \%$ of Hong Kong's primary school teachers and 30\% of secondary school teachers are graduates of HKIEd or its predecessor colleges of education. The institute is a pioneer in early childhood education and has trained, over the years, some $80 \%$ of Hong Kong's kindergarten teachers. To be vigilant in peace time, a throughout understanding of the sources of the prospect students can better prepare the institute for future challenges.

The institute's programme spectrum was expanded and enhanced quite drastically since 2005 with the introduction of 1st Master in Education cohort. Currently, it offers both Research Postgraduate (RPg) Programmes (i.e. $\mathrm{PhD}$ and MPhil) and taught postgraduate programmes including the Master of Education (MEd) Programme and the Doctor of Education (EdD) Programme. It also offers a number of Master of Arts (MA) programmes. How can we better utilize this rich collection of programmes to reinforce institute's strength and reputation is the aim of this paper.

In this paper we focus on identifying usable admission patterns by analyzing admission data of the past years. In particular, it is focused to find out: 1. any internal competition and how the competition is? 2. any programme which can be utilized as strategic recruitment? I.e. any programme that can bring more students in future; and 3. the general trend in student admission. At this point, we are not suggesting recruitment strategy as this falls outside the scope of the study. However, this paper serves as a useful reference for defining recruitment strategy.

Therefore, there is not much literature that focuses on admission issues in the teacher education programs in Hong Kong. Some studies linked to the normative component of the selection problem focus primarily on an imperative of a diversification of the teaching force in the face of a linguistically and culturally diverse student population[1]. Some literature use the selection problem empirical component to study the connections between applicants' qualities (e.g. GPA, interviews, or written profiles) - and educational learning outcomes for those admitted into the program(s)(e.g. successful student teaching, successful program completion, or successful teaching after graduation)[2]. In[3], the relationship between the admission desired qualities criteria and the type of the graduates' working and hiring conditions in school divisions is studied. Practices in admissions processes to maintain and refine the quality of the teacher 
education is studied by[4]. The factors for admission rejection is discussed in [5] and[6]focuses in the marketplace view of the admission process, students are regarded as consumer and the competition between universities and colleges are analyzed. Especially in Hong Kong, the universities are engaged in a competition for their share of the education market, with the overwhelming advertising on newspaper, TV and Internet; competing for students not only in terms of academic programs, prestige, and reputation, but also on the quality of student service delivery and value of student experiences outside of the classroom. For students' continuous study, [7] and[8]proposed some methods and policies to design the courses and programs, while few researchers study the relationships between the different programmes from the admission data, since most applicants submit more than 1 applications to HKIEd, and our work can help the Institute to lay more efforts to the potential target students, by using the waterfall model(a well-known item in computer science area).The methods used in this paper can be easily applied in other universities for analyzing the admission issues

\section{TIME PERIOD 2007 TO 2011}

From the year 2007 to 2011, main applications are from local Hong Kong and there is intense competition not only among the Universities in Hong Kong[9, 10], but also the different programmes in HKIEd. To clearly show our work and effort, the idea map is shown below. We analyses the admission data by different factors, e.g. Source of applications; Quality of applications (age, Working experience, Years since last study).MS SQL and SSPS are used to facility the study.

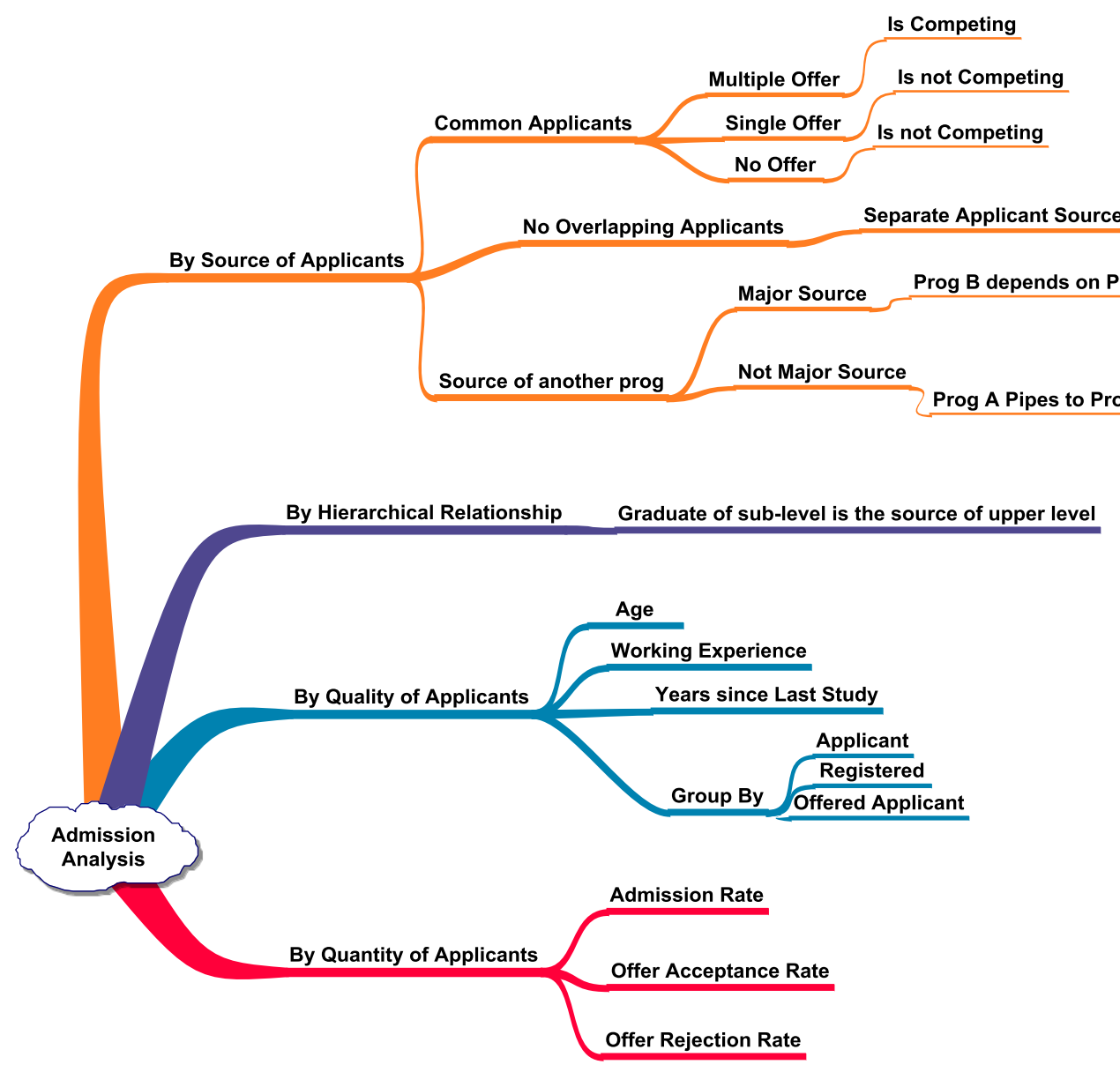

Fig. 1. Idea Map of Admission Analysis for the Period I

In addition to basic statistical analysis, data mining technique was also employed in this exercised. In particular, data was mined to find out the patterns of inter-competition programmes and strategic recruitment programmes. Before 2011, programme application was peer group basis; there could be more than one programme in an admission group. Hence, programme competition within a group was not genuine and was excluded in this analysis. This policy was updated to single programme per application in 2011. Data was minded to find out the yearly association in order to identify internal competition. The data mining technique, Generalized Sequential Pattern (GSP)[11] was used. As shown in the below algorithm, when a sequence is identified, the corresponding discussion with relevant unit was made to decide if it was a genuine one that worth noting and follow up in the next section. 
$\mathrm{F} 1=$ the set of frequent 1-sequence

$\mathrm{k}=2$,

do while $\mathrm{F}(\mathrm{k}-1)$ != Null;

Generate candidate sets $\mathrm{Ck}$ (set of candidate ksequences);

For all input sequences $s$ in the data set D do

Increment count of all a in $\mathrm{Ck}$ if s supports a

$\mathrm{Fk}=\{\mathrm{a} \in \mathrm{Ck}$ such that its frequency exceeds the threshold ;

$\mathrm{k}=\mathrm{k}+1$;

Result $=$ Set of all frequent sequences is the union of all Fks

End do

End do

After the processing, we find that there are 2 patterns for the programmes- Waterfall [12] and Competing Pattern, which are shown in Fig. 2. Some programmes with applicant overflow from one to the other. As illustrated in Fig.2, unsuccessful applicants of programme A are invited to apply programme B which probability contributed to the major source of applicant of programme B.

And some programmes are competing with each other's. As illustrated in Fig. 2. There is a group of applicants who apply the two programmes at the same time. If these applicants are admitted by both programme, only one will prevail. We explain these 2 patterns with detail programmes information below.

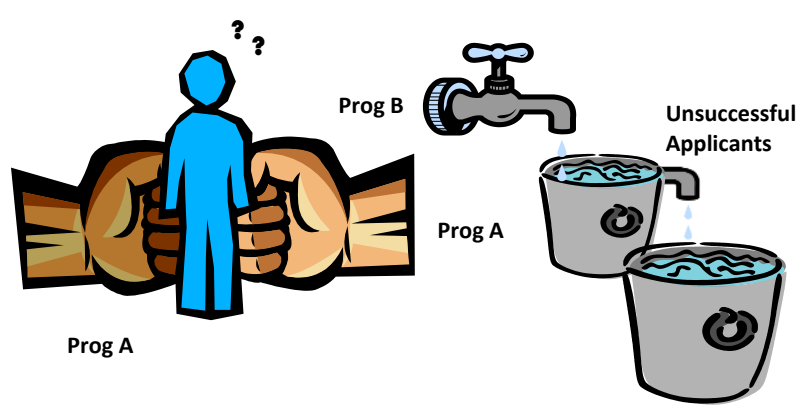

Fig. 2. Waterfall and Competing Pattern

\section{1) 1 - Waterfall Programmes}

As shown in TABLE I, the applications for programme-BEd (ECE) (Bachelor of Education (Early Childhood Education)) \& HD (ECE) and HD (ECE) (Higher Diploma in Early Childhood Education), 3 Year Full-time falls into Waterfall Pattern. In 2010, there were 762 applicants who also applied both $\mathrm{HD}(\mathrm{ECE})$ and
Bed(ECE) \& HD(ECE) which were $84.1 \%$ of $\mathrm{HD}(\mathrm{ECE})$; these were, both JUPAS(Joint University Programmes Admissions System) and non-JUPAS applicants who were not successful for $\mathrm{HD}(\mathrm{ECE})$ nor BEd(ECE) and indicated interest in $\mathrm{HD}(\mathrm{ECE})$.

Table 1. Application Details of Waterfall Programmes

\begin{tabular}{|c|c|c|}
\hline Year & \% of Total HD(ECE) 3 Year Full-time & Admission Rate \\
\hline 2009 & $80.1 \%$ & 0.08 \\
\hline 2010 & $84.1 \%$ & 0.06 \\
\hline
\end{tabular}

\section{1) 2 - Competing Programmes}

True programme competition occurs when there are applicants who applied two programmes and received offers from both programmes. In HK, for non-JUPAS applicants, there was a competition between BA_LANG (Bachelor of Arts in Language Studies) and BSocSci (Bachelor of Social Sciences Curriculum) (TABLE II). For non-JUPAS applicants, there were 34 applicants who applied both BA_LANG and BSocSci which were $14.7 \%$ of BA_LANG (232) and 21.2\% of BSocSci (160) (TABLE III). Within these 34 applicants, there were 4 who received two offers. The preference ratio is $3: 1,3$ BA (Bachelor of Arts) to 1 BSocSci.

Different from HK, where BA and BSocSci was competing, in Mainland, the competition was between Bed \& BSocSci. There were 28 mainland applicants who applied both Bed (Bachelor of Education) and BSocSci which were $13.5 \%$ of BEd (208) and $50.9 \%$ of BSocSci (55). However, since there was no applicant who received two offers, hence, this was not a sound competition. (TABLE IV, V)

Competition also existed in UGC (University Grants Committee) funded and self-financed undergrad programme, Bed \& BME. At least $30 \%$ of BME applicant also applied BEd via JUPAS and non-JUPAS routes. A trend was form that BME (Bachelor of Music Education) would win students over BEd, though the numbers were still minutes as compared to the pool of BEd students. A true competition had been formed. (TABLE VI, VII)

In summary, there were three pairs of competing programmes, namely, (HK) BME \& BEd, (HK NonJUPAS) BA_LANG \& BSocSci and (Mainland) BEd\&BSocSci. The former two pairs were genuinely competing programmes. Also, it is commonly believed that MEd and PGDE (Postgraduate Diploma in Education) are competing since they are both postgraduate programmes. In fact, this is a myth, from the above analysis; there was no evident showing this. Because MEd and PGDE were targeting two different groups of applicants.

Table 2. Non-JUPAS application details of Competing Programmes

\begin{tabular}{|c|c|c|c|c|c|c|c|c|c|}
\hline & Programme & $\begin{array}{c}\text { No. of } \\
\text { Common } \\
\text { Applicants }\end{array}$ & $\begin{array}{c}\text { Total } \\
\text { Applicants }\end{array}$ & $\begin{array}{c}\text { Confident } \\
\text { Level }\end{array}$ & $\begin{array}{l}\text { Admission } \\
\text { Rate of the } \\
\text { Programme }\end{array}$ & $\begin{array}{c}\text { Common } \\
\text { Applicants with } \\
\text { Single Offer }\end{array}$ & $\begin{array}{c}\text { Registered } \\
\text { Applicants with } \\
\text { Single Offer }\end{array}$ & $\begin{array}{c}\text { Common } \\
\text { Applicants with } \\
\text { both offers }\end{array}$ & $\begin{array}{l}\text { Preference } \\
\text { of } \\
\text { Common } \\
\text { Applicants }\end{array}$ \\
\hline \multirow{2}{*}{$\begin{array}{c}201 \\
0 \\
\end{array}$} & BA_LANG & \multirow{2}{*}{34} & 232 & 0.147 & $15.5 \%(36)$ & 5 & 4 & \multirow{2}{*}{4} & 3 \\
\hline & BSocSci & & 160 & 0.212 & $3.8 \%(6)$ & 3 & 1 & & 1 \\
\hline
\end{tabular}


Table 3. Non-JUPAS registration details of competing programmes

\begin{tabular}{|r|c|r|c|c|c|c|}
\hline & Programme & Total Applicant & Registered & Singular Prog Applicant & Common with Single Offer & Common with Double Offer \\
\hline 2010 & BA_LANG & 232 & $36(15.5 \%)$ & $29(80.6 \%)$ & $4(11.1 \%)$ & $3(8.3 \%)$ \\
\hline & BSocSci & 160 & $6(3.8 \%)$ & $4(66.7 \%)$ & $1(16.7 \%)$ & $1(16.7 \%)$ \\
\hline
\end{tabular}

Table 4.Mainland applicant details of competing programmes

\begin{tabular}{|c|c|c|c|c|c|c|c|c|c|}
\hline & Programmes & $\begin{array}{c}\text { No. of } \\
\text { Common } \\
\text { Applicants } \\
\end{array}$ & $\begin{array}{c}\text { Total } \\
\text { Applicants }\end{array}$ & $\begin{array}{l}\text { Confident } \\
\text { Level }\end{array}$ & $\begin{array}{l}\text { Admission } \\
\text { Rate of the } \\
\text { Programme }\end{array}$ & $\begin{array}{c}\text { Common } \\
\text { Applicants with } \\
\text { Single Offer }\end{array}$ & $\begin{array}{c}\text { Registered } \\
\text { Applicants with } \\
\text { Single Offer }\end{array}$ & $\begin{array}{c}\text { Common } \\
\text { Applicants with } \\
\text { both offers }\end{array}$ & $\begin{array}{c}\text { Preference } \\
\text { of Common } \\
\text { Applicants } \\
\end{array}$ \\
\hline 2010 & BSocSci & \multirow{2}{*}{28} & 55 & 0.509 & $12.7 \%(7)$ & 2 & 2 & \multirow[t]{2}{*}{ 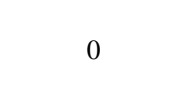 } & 0 \\
\hline & BEd & & 208 & 0.135 & $20.7 \%(43)$ & 4 & 4 & & 0 \\
\hline
\end{tabular}

Table 5. Mainland registration details of competing programmes

\begin{tabular}{|r|c|r|c|c|c|c|}
\hline & Programme & Total Applicant & Registered & Singular Prog Applicant & Common with Single Offer & $\begin{array}{c}\text { Common with Double } \\
\text { Offer }\end{array}$ \\
\hline 2010 & BSocSci & 55 & $7(12.7 \%)$ & $5(71.4 \%)$ & $2(28.6 \%)$ & $0(0 \%)$ \\
\hline & BEd & 208 & $43(20.7 \%)$ & $39(90.7 \%)$ & $4(9.3 \%)$ & $0(0 \%)$ \\
\hline
\end{tabular}

Table 6. UGC funded and self-financed applicant details of competing programmes

\begin{tabular}{|c|c|c|c|c|c|c|c|c|c|}
\hline & Programmes & $\begin{array}{c}\text { No. of } \\
\text { Common } \\
\text { Applicants }\end{array}$ & $\begin{array}{c}\text { Total } \\
\text { Applicants }\end{array}$ & $\begin{array}{c}\text { Confident } \\
\text { Level }\end{array}$ & $\begin{array}{c}\text { Admission } \\
\text { Rate of the } \\
\text { Programme }\end{array}$ & $\begin{array}{c}\text { Common } \\
\text { Applicants with } \\
\text { Single Offer }\end{array}$ & $\begin{array}{c}\text { Registered } \\
\text { Applicants with } \\
\text { Single Offer }\end{array}$ & $\begin{array}{c}\text { Common } \\
\text { Applicants with } \\
\text { both offers }\end{array}$ & $\begin{array}{c}\text { Preference of } \\
\text { Common } \\
\text { Applicants }\end{array}$ \\
\hline $\begin{array}{c}200 \\
8\end{array}$ & BME & 31 & 88 & 0.352 & $36.4 \%(32)$ & 12 & 12 & 0 \\
\hline & BEd & & 14405 & $>0.05$ & $4.1 \%(591)$ & 0 & 0 & 0 \\
\hline $\begin{array}{c}200 \\
9\end{array}$ & BME & 50 & 94 & 0.532 & $62.2 \%(34)$ & 15 & 14 & 0 \\
\hline & BEd & & 13958 & $>0.05$ & $5.0 \%(697)$ & 1 & 1 & $2(0 \%)$ \\
\hline $\begin{array}{c}201 \\
0\end{array}$ & BME & 41 & 130 & 0.315 & $33.8 \%(44)$ & 16 & 8 & 20 \\
\hline
\end{tabular}

Table 7. UGC funded and self-financed registration details of competing programmes

\begin{tabular}{|c|c|r|c|c|c|c|}
\hline & Programme & Total Applicant & Registered & Singular Prog Applicant & Common with Single Offer & Common with Double Offer \\
\hline 2008 & BME & 88 & $32(36.4 \%)$ & $20(62.5 \%)$ & $12(37.5 \%)$ & $0(0 \%)$ \\
\hline & BEd & 14405 & $591(4.1 \%)$ & $591(100 \%)$ & $0(0 \%)$ & $0(0 \%)$ \\
\hline 2009 & BME & 94 & $34(62.2 \%)$ & $18(52.9 \%)$ & $14(41.2 \%)$ & $2(5.9 \%)$ \\
\hline & BEd & 13958 & $697(5.0 \%)$ & $682(97.8 \%)$ & $1(0.1 \%)$ & $14(2.0 \%)$ \\
\hline 2010 & BME & 130 & $44(33.8 \%)$ & $34(77.3 \%)$ & $8(18.2 \%)$ & $2(4.5 \%)$ \\
\hline & BEd & 16756 & $785(4.7 \%)$ & $780(99.4 \%)$ & $2(0.3 \%)$ & $3(0.4 \%)$ \\
\hline
\end{tabular}

\section{1) Considerations}

From the above analysis, for the programme-MEd, HKIEd now is offering a full spectrum of programmes from AD, Pre-AD to Taught Postgraduate \& Research Postgraduate. However, it is not significant that the source of applicants of MEd may be hitting its limit of growth; in 2008 the growth was by $20 \%$, in 2009 , it was $13 \%$ and only $3 \%$ in 2010 . There was a major curriculum update in 2009, perhaps this partly contributed to the phenomenon. Or it could be due to feedback from MEd graduates. (Fig.3)

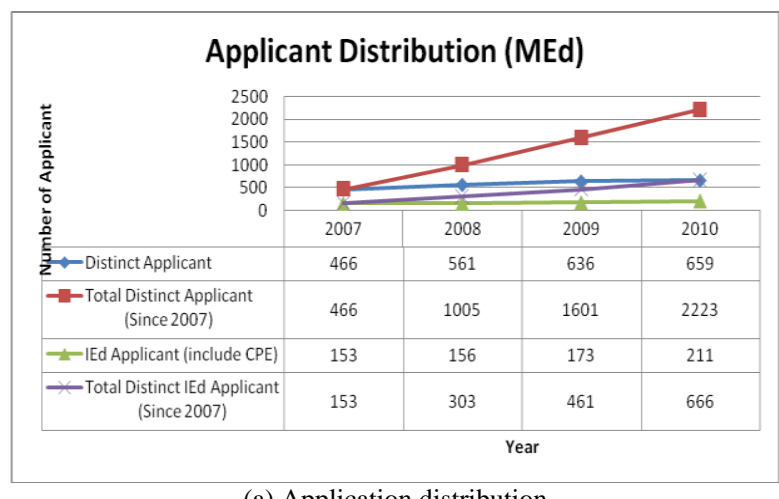

(a) Application distribution 


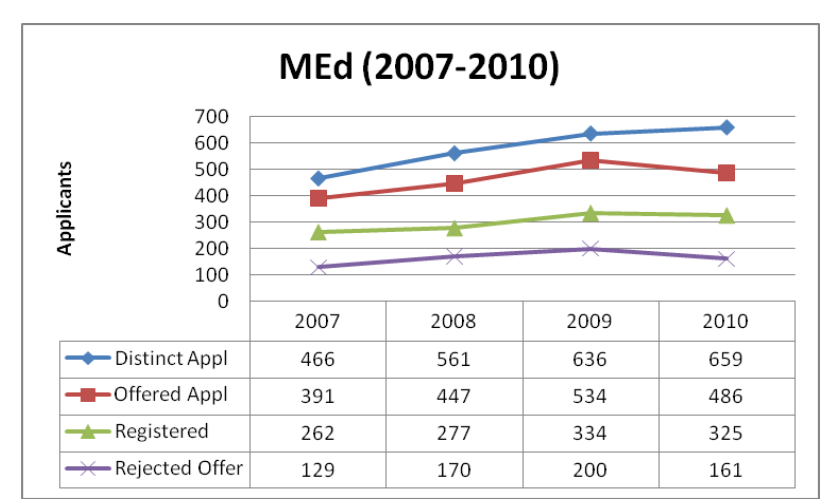

(b) Application status

Fig. 3. Application distribution and status of the programme- MEd

In 2010, HKIEd was more selective in making offer to quality applicants. According to Graduate School, the entrance requirements were not changed in 2010. As discussed with Graduate School, part of the drop in programme offer could be due to the new policy that any specialization/course with less than 15 students will need the endorsement of the Faculty Deans and some specializations were cancelled due to low application.. However, it was believed that this new policy was not the only factor that contributed to the drop in offer number. This drop in offering could be a signal that worth noting; it may indicate the limit in the quality of applicants. As of now, the signal is not strong but it should be monitored closely in the coming years. (Fig.3)

On average, $30 \%$ of MEd applicants were our graduates, including CPE (Continuing and Professional Education) students. This ratio was consistent throughout the stages of admission, application, offered and registered. The rejection rates were slightly higher for non-IEd applicants, also $30 \%$, was similar amongst IEd and Non-IEd applicants. I.e. 2/3 of MEd students were non-IEd graduates. (Table VIII, IX)(Fig.4)

Within this $30 \%$ of IEd applicants, about $80 \%$ were fresh graduates within 3 years. The overall portfolio showed $60 \%$ were fresh graduates within 3 years.

Table 8. Application of the programme- Med

\begin{tabular}{|c|c|c|c|c|c|}
\hline \multicolumn{2}{|c|}{ Applicants with Offers } & & & & \\
\hline & Total & IEd & & non-IEd & \\
\hline 2007 & 391 & 137 & $35.04 \%$ & 254 & $64.96 \%$ \\
\hline 2008 & 447 & 136 & $30.43 \%$ & 311 & $69.57 \%$ \\
\hline 2009 & 534 & 156 & $29.21 \%$ & 378 & $70.79 \%$ \\
\hline 2010 & 486 & 151 & $31.07 \%$ & 335 & $68.93 \%$ \\
\hline Medium & & & $30.75 \%$ & & $69.25 \%$ \\
\hline Average & & & $31.44 \%$ & & $68.56 \%$ \\
\hline
\end{tabular}

Table 9. Decline offer distribution of the programme- Med

\begin{tabular}{|c|c|c|c|c|c|}
\hline \multicolumn{2}{|l|}{ Decline Offer } & & & & \\
\hline & Total & IEd & & Non-IEd & \\
\hline 2007 & 129 & 48 & $35.04 \%$ & 81 & $31.89 \%$ \\
\hline 2008 & 170 & 53 & $38.97 \%$ & 117 & $37.62 \%$ \\
\hline 2009 & 200 & 46 & $29.49 \%$ & 154 & $40.74 \%$ \\
\hline 2010 & 161 & 42 & $27.81 \%$ & 119 & $35.52 \%$ \\
\hline Medium & & & $32.26 \%$ & & $36.57 \%$ \\
\hline Average & & & $32.83 \%$ & & $36.44 \%$ \\
\hline
\end{tabular}

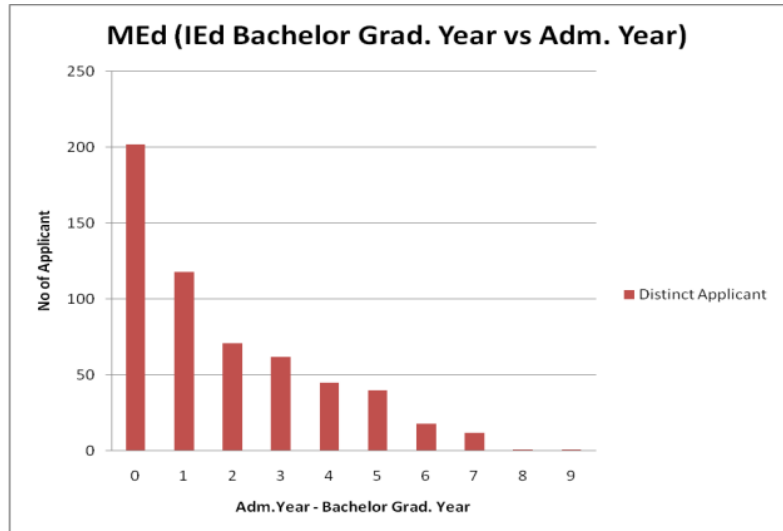

(a) IEd Bachelor

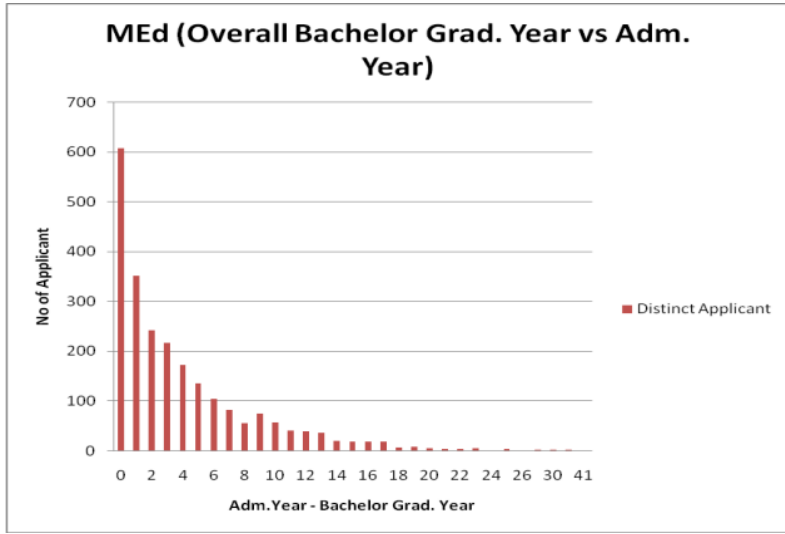

(b) Overall Bachelor

Fig. 4. IEd Bachelor \&Overall Bachelor Grad. Year vs Adm. Year of the programme- Med

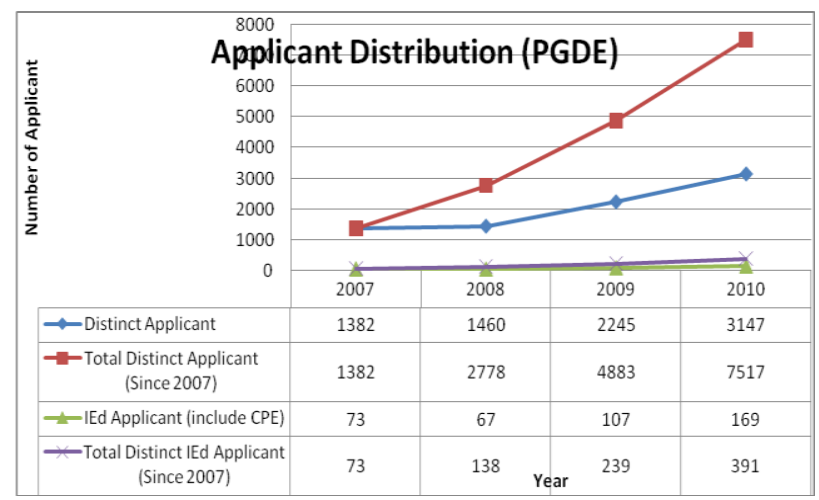

(a) Application distribution

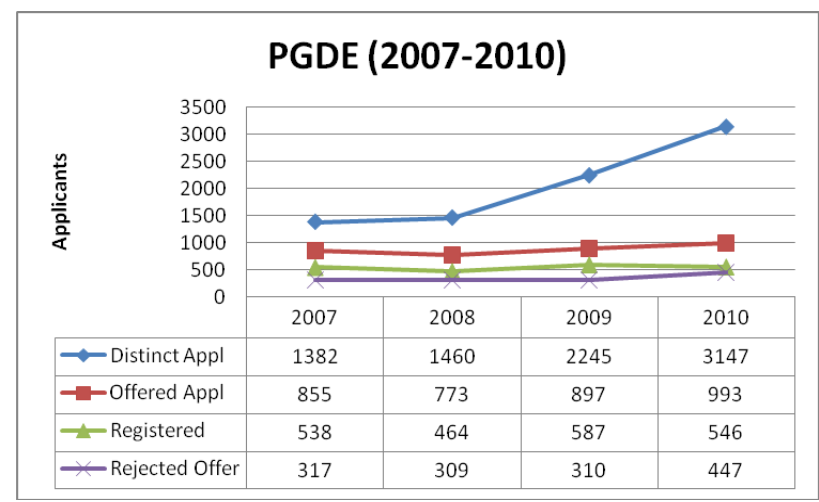

(b) Application status

Fig. 5. Application distribution and status of the programme- PGDE 
It is commonly believed that MEd and PGDE are competing since they are both postgraduate programmes. In fact, this is a myth, from the above analysis result; there was no evident showing this. MEd and PGDE were targeting two different groups of applicants.

For the programme-EdD (Doctor of Education), there was a slowdown in intake; in 2010 it was only 49, 4 more than 2009. There was also a slowdown in applicants of 2010 but an increase in making offers. This implied the institute was attracting quality applicants instead of quantity. At the same time, external competition was also keen, this accounted for a highest offer rejection rate of the 4 years. If this pattern persists, i.e. slowdown in applicant number, high offer and rejection rates, this may be a signal on the competitiveness of EdD programme. (Fig.6)

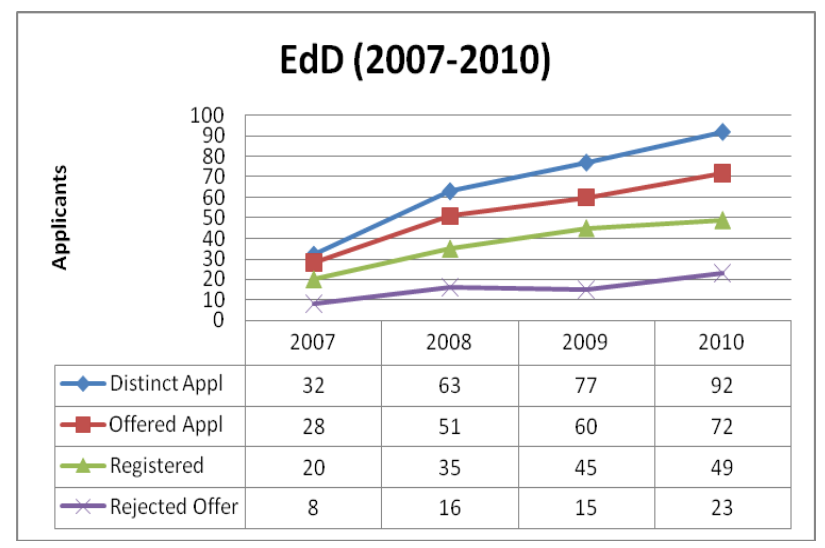

Fig. 6. Application status of the programme- EdD

\section{TIME PERIOD 2011 TO 2013}

For the time slot 2011-2013, HKIEd attracts many applications from mainland China[13][14][15][16], and due to the large demand of the primary and secondary school teachers[17][18] for the 3-3-4 Scheme Education System Reform in 2012[19][20], many local students apply the Master programmes of HKIEd. For example, in 2013, HKIEd admitted 812 students to 18 self-financed programme groups with 6 new programmes, 391 were from local, 415 from mainland and only 6 from overseas. The ratio of local to mainland was 0.94 : 1 ; ratio of the year 2012 is 1.3:1. The overall applicant profile had shifted from local to mainland students, and attracted $52 \%$ more applicants, and recruited 812 students which were $159 \%$ of that of the year 2012 .

Towards the year2007-2010, we also draw our method into the Fig. below for listing the factors we used for the analyzing. For the continuous study and comparison, the Fig. below contains the data from 2008 to 2013, so that it is easy to find the changes in 2011 and 2012.

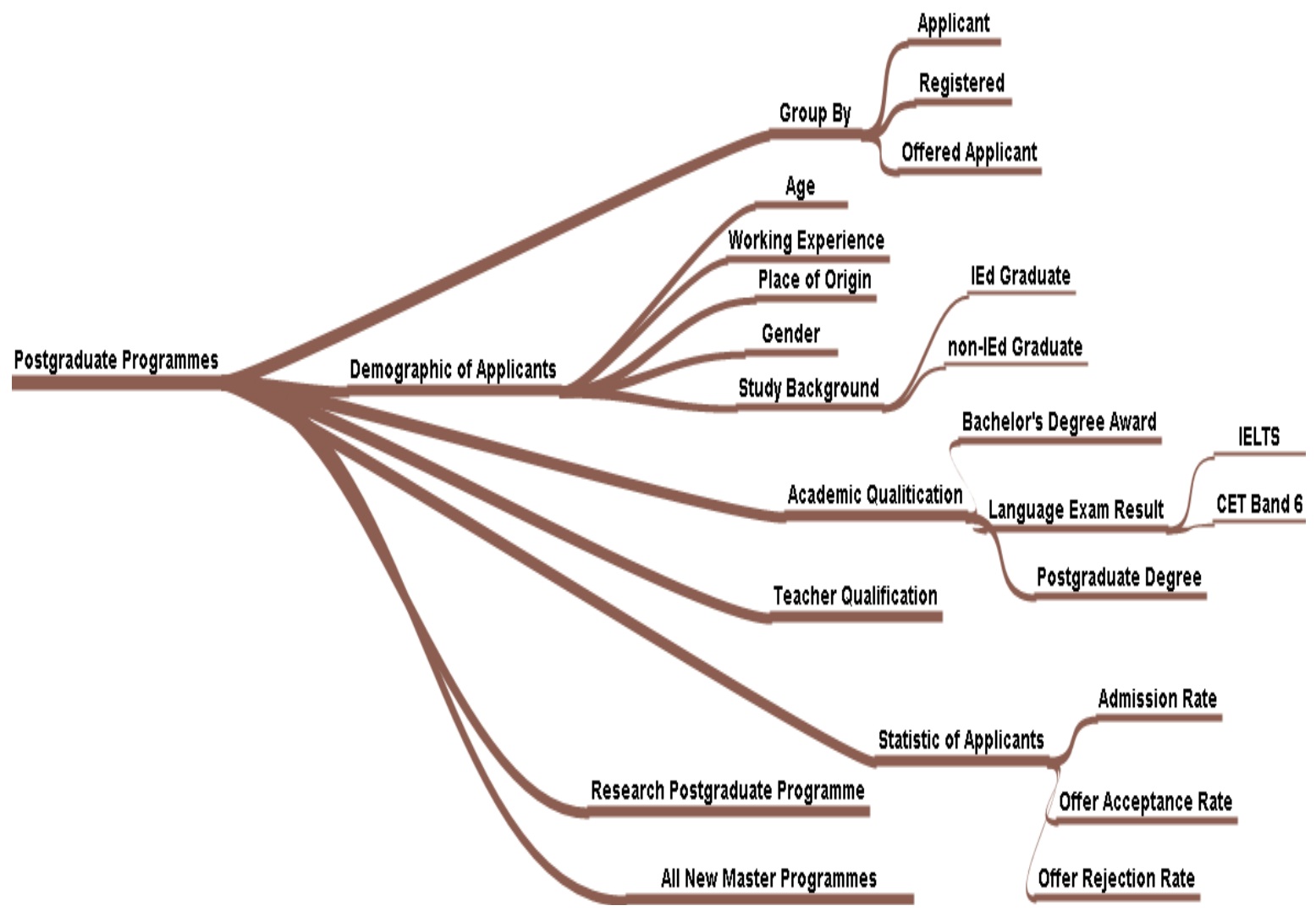

Fig. 7 Idea Map of Admission Analysis for the Period II 


\section{1) Programme Mainland Vs Local Students}

Continuing the trend of last year as shown below, for self-financed programmes, the applicant profile has significantly shifted from local to mainland students. As of January 2014, the institute admitted 812 students to self-financed programmes. 931 were from local, 415 from mainland and only 6 from overseas. The ratio of local to mainland is 0.94 : 1 , ratio of last year is $1.3: 1$. When compared to the geographic distribution of last year, the overall applicant profile had shifted from local to mainland students. This year the institute attracted $52 \%$ more applicants, and recruited 812 students which were $159 \%$ of last year. (Fig.8)

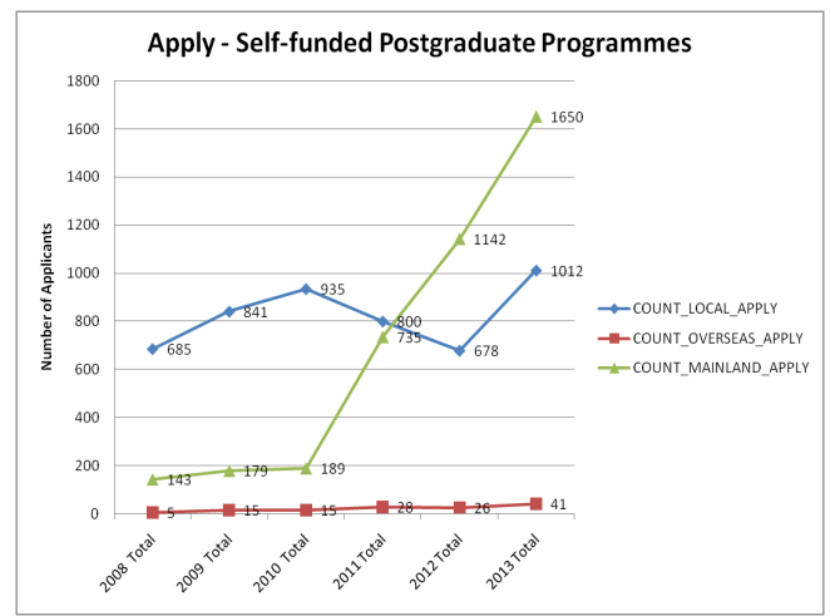

(a) Application distribution

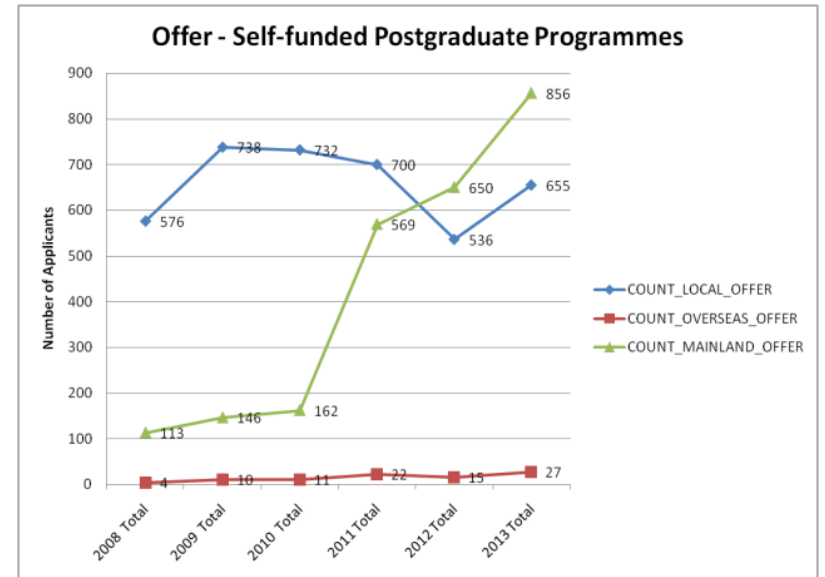

(b) Application status

Fig. 8. Application\&Offer distribution of the Self-funded Postgraduate programmes

\section{2) Overall Performance}

As compared to last year (2011), the institute had successfully recruited $183(29 \%)$ more postgraduate students to self-financed programmes, a total of 812 students. The largest programme group remains as MEd, followed by MACSLE (in 2 consecutive years) and MPPG (new programme) (Fig.9)

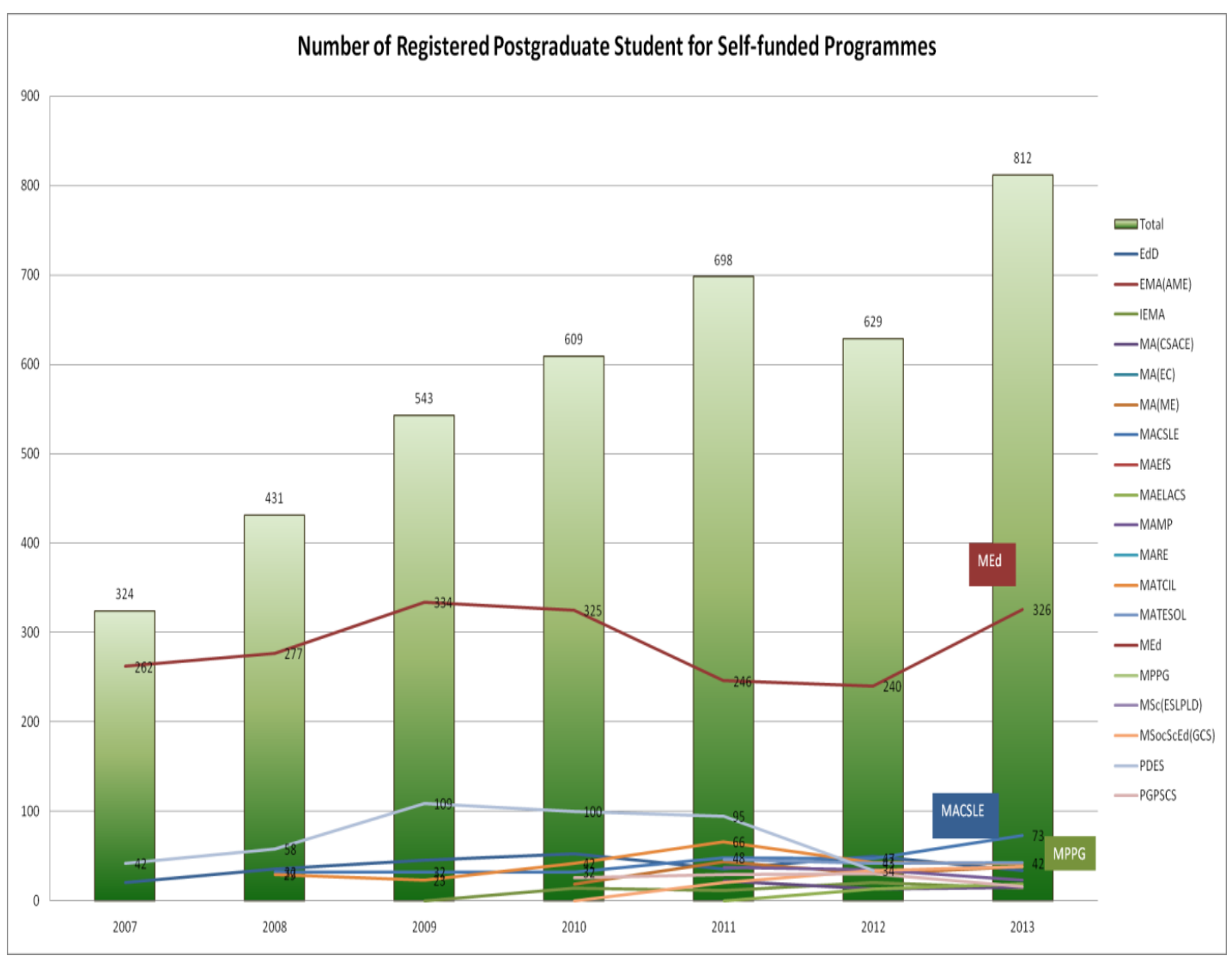

Fig. 9. Number of registered of postgraduate students for the Self-funded programmes 
The demographic information such as age, place of origin, academic qualification, teacher qualification, language exam result, admission rate, acceptance rate and offer rejection rate, retention rate of each programme can be found in Appendix I Programme Admission Profile.

\section{3) Research Postgraduate Programmes (A3D054, A2M053)}

Currently, HKIEdis offering UGC-funded Doctor of Philosophy and Master of Philosophy. First installation of programmes was in 2009. Since then, programmes are gaining their popularities, the applicant volume tripled up in 2011. In the year-2013, the institute gained more attraction in both MPhil and PhD and abled to admit more students than previous year. The acceptant rate was also as high as $90 \%$. (Fig.10).

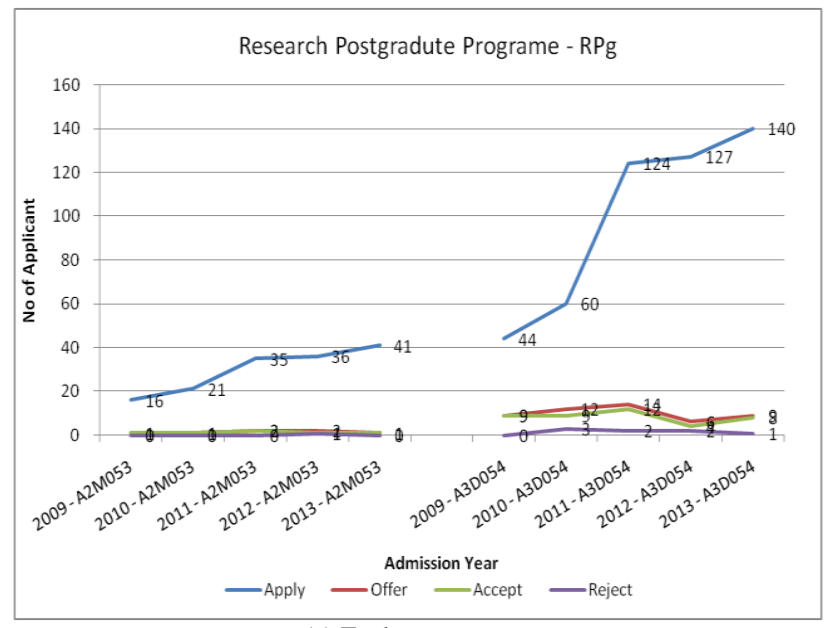

(a) Each programme

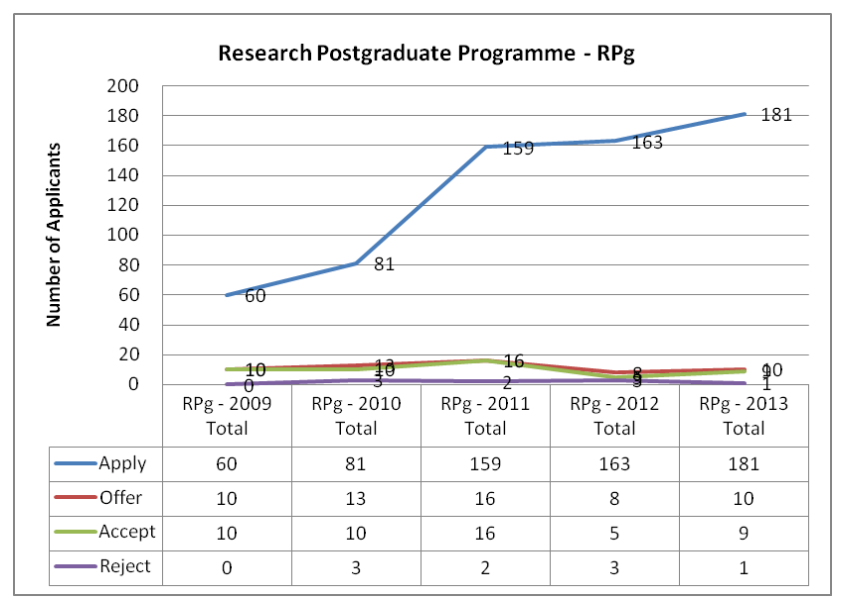

(b) In all

Fig. 10. Numbers of Applicant of the research postgraduate programme (A3D054, A2M053) and in total

\section{4) Doctor of Education (A3D045 \& C4D001}

The increment of applications to 4-year programme was offset by that of 3 year programme, resulting to a flattened number of applications in 2012 \& 2013. Though applications are similar in these two years, the institute only admitted 47 student in 2013, 67\% of that of 2012 . Starting from 2011, application is not in proportion to the offering and acceptance. This implies than more students. Applicationsare not in proportion to offering and acceptance (Fig. 11).

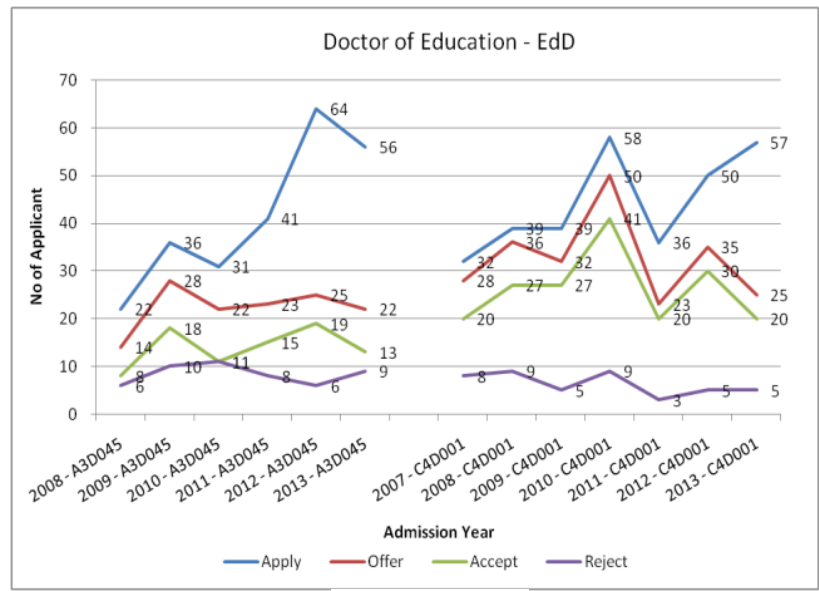

(a) Each programme

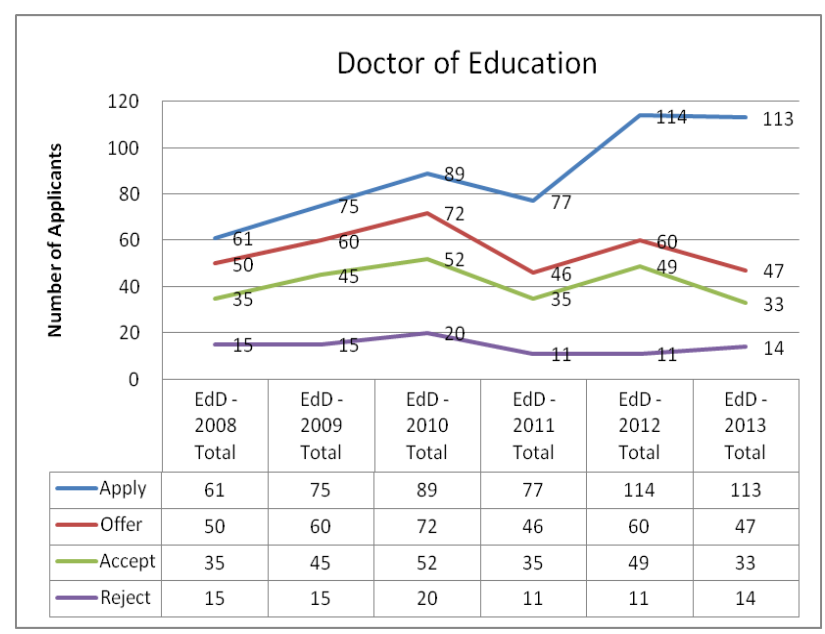

(b) In all

Fig. 11. Application status of the EdD for the programme-A3D045 \& C4D001and in total

\section{5) Master of Education (A1M043 \& C2M001)}

Both full-time and part-time had attracted more applicants this year, a total of 794, or 193 more than last year. This is also the major contribution to the overall increment of postgraduate applicants. The admission is also higher than last year. A total of 326 students, 86 more than last year were admitted to the programme group, second record high since inception of the programme group. From the charts below, it is obvious that full-time mode of the programme have over taken the attractiveness of part-time mode of study. An important signal is observed, for full-time mode of study, since last year, about half of the offerings were rejected. This is a signal to be monitored which can be used to gauge the attractiveness of the programme. ---50\% of offers are rejected. (Fig. 12). 


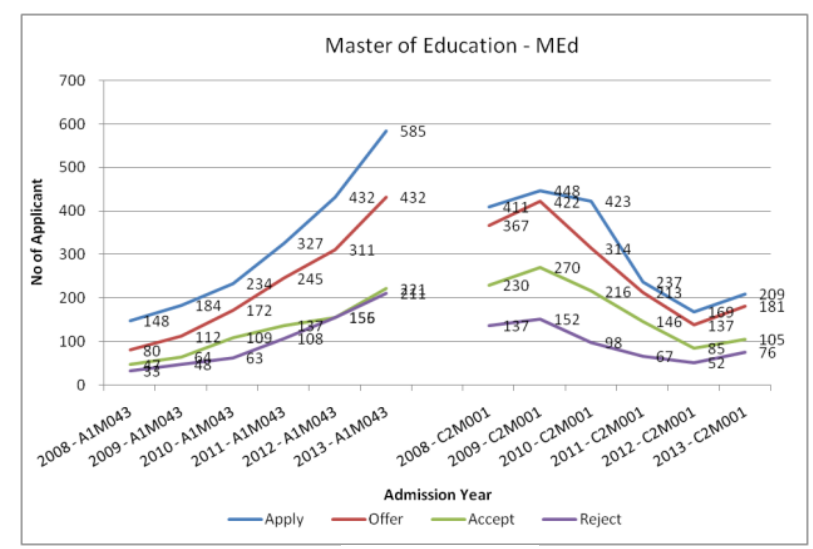

(a) Each programme

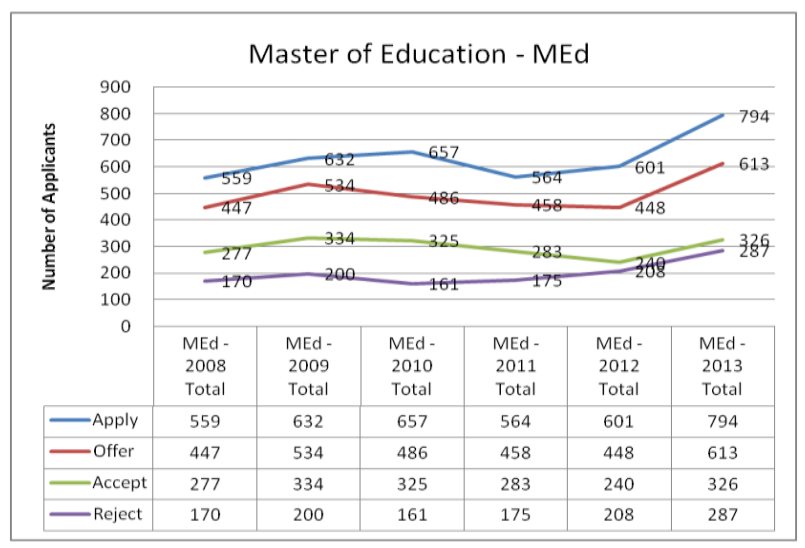

(b) In all

Fig. 12. Application status of MEd for the programme-A1M043 \& $\mathrm{C} 2 \mathrm{M} 001$, and in total

6) Postgraduate Diploma in Psychology (Schools and Community Settings)(A1P017 \& C2P047)

There is a significant drop in admission of the programme group, a drop of $47 \%$ when compared to last year. The decrement is mainly from part-time mode of study; last year, there were 24 students but this year only 6 showed up. For full-time mode, the rejection rate is also high; though the institute made more offer than last year, 27 as compared to 13 , only 10 show up. 2014 may be a challenging year for this programme group.Downward trend occurs in student acceptance. (Fig. 13)

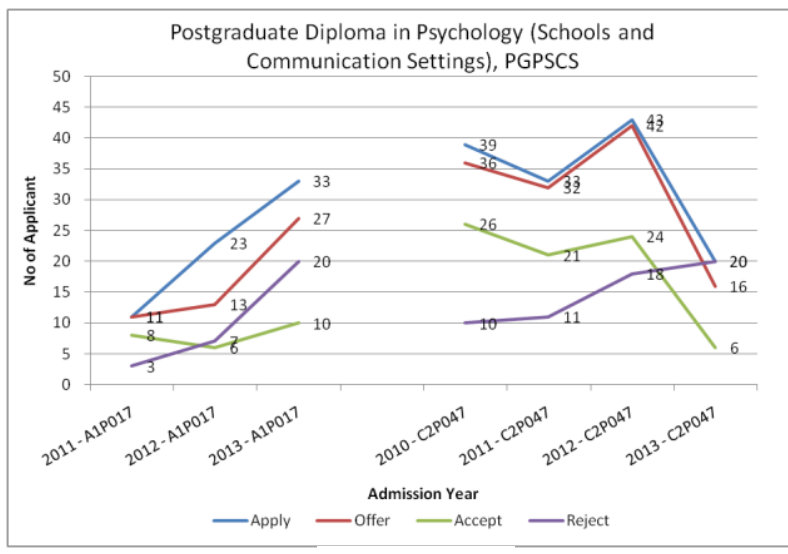

(a) Each programme

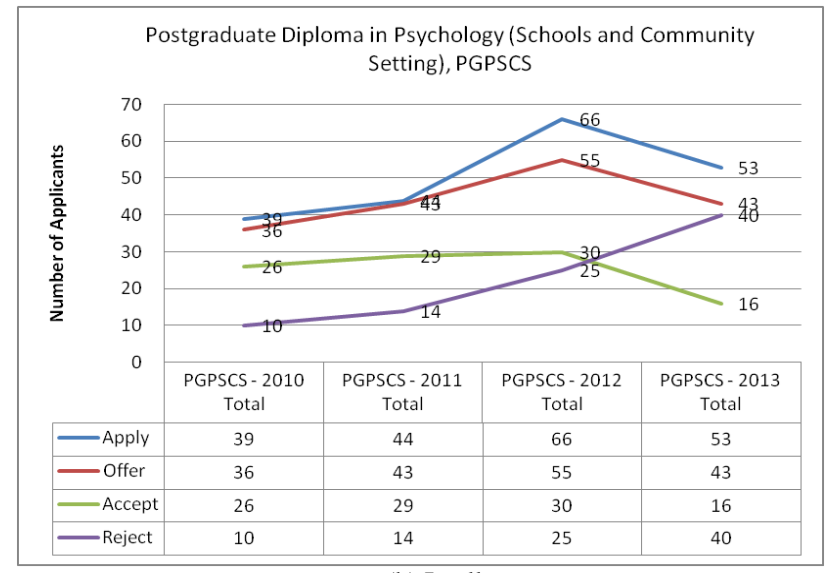

(b) In all

Fig. 13.Application status of Postgraduate Diploma in Psychology for the programme-A1P017 \& $\mathrm{C} 2 \mathrm{P} 047$, and in total

7) Master of Arts in Chinese Studies (Language Education) (A1M052, C2M002)

This is the second largest postgraduate programme groups. This programme obviously attracted more mainland students than local ones, $72 \%$ applicants were from mainland, $3 \%$ higher than last year. However, there was also high rejection rate. With the 73 students accepted the offers, 38 was from mainland, contributed to $52 \%$ of the total, $7 \%$ higher than last year. (Fig. 14)

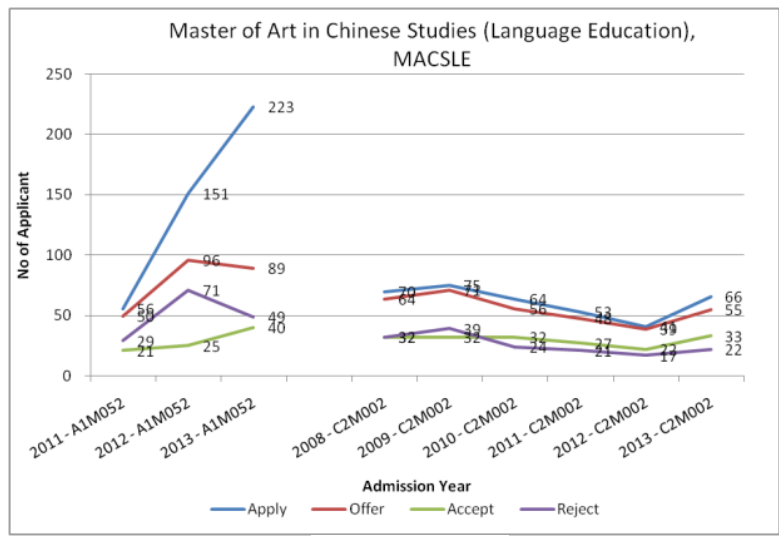

(a) Each programme

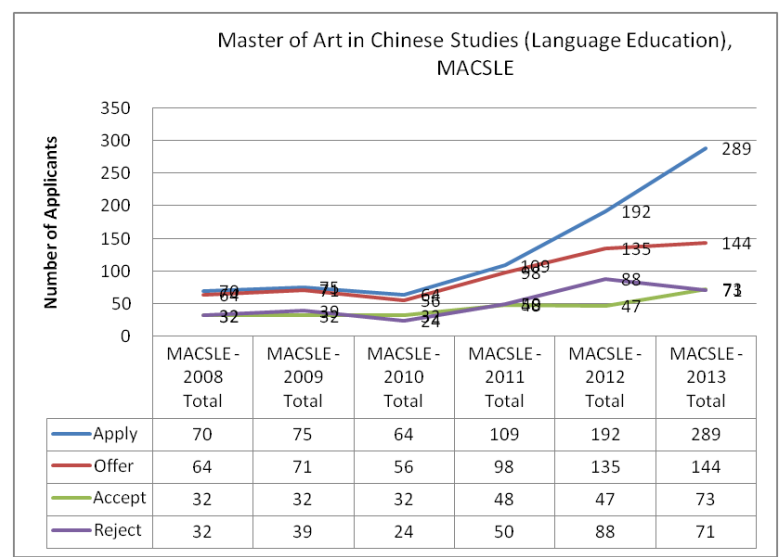

(b) In all

Fig. 14 Application status of Master of Arts in Chinese Studies for the programme-A1M052, C2M002, and in total 


\section{8) Master of Arts in Teaching English to Speakers of} Other Languages (A1M057, C2M010)

The programme group continued to attract more applicants. The increment in applications was from mainland. There is a distinct pattern of the group; the rejection of full-time programme is higher than the acceptance of the programme. This may indicate that the programme is not a preferred choice of many applicants; applicants will give up offers when they have offers from other institutes or other programmes of IEd. This is a signal to be observed. (Fig. 15)

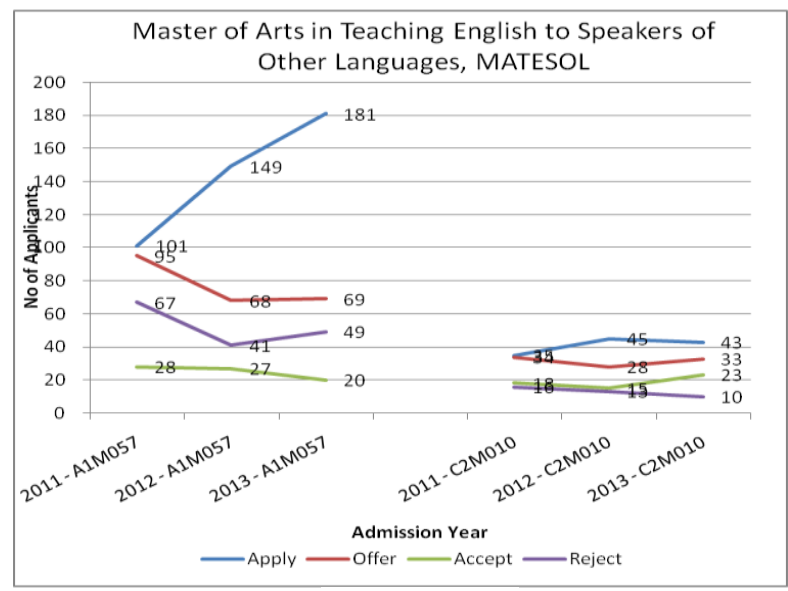

(a) Each programme

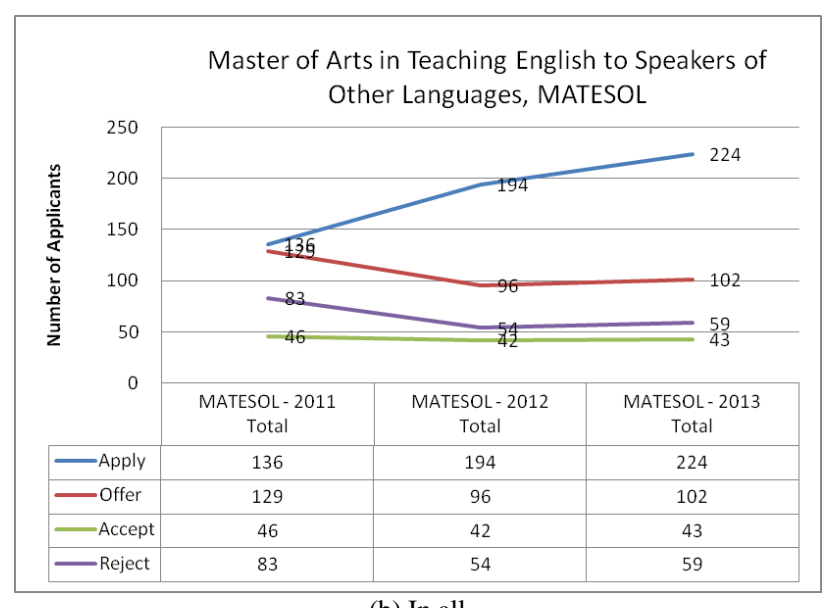

(b) In all

Fig. 15 Application status of Master of Arts in Teaching English to Speakers of Other Languages (A1M057, C2M010), and in total

\section{CONCLUSIONS}

This paper is the first attempt to analyze the admission data in order to identify signals for further monitoring and follow up works in the college level of Hong Kong.

Due to the high competition of Hong Kong education market, it is demanded to analyze and evaluate the programme development, not only in terms of academic programs, prestige, and reputation, but also on the quality of student service delivery and value of student experiences outside of the classroom.
By quantitatively studying the relationships between the different programmes from the 8 years' student admission data of HKIEd in 2 time slots, the signal we found as competition of (HK) BME \&BEd, (HK NonJUPAS) BA_LANG \&BSocSci and (Mainland) Bed $\&$ BSocSci in the $1^{\text {st }}$ time slot, and the further general student admission trend is studied for the $2^{\text {nd }} \operatorname{slot}(2011$ 2013), to analyze the effects of the sharp increase of mainland China students and the3-3-4 Scheme Education System Reform in 2011 and 2012.

The institute's strength and reputation is expanded and enhanced from the suggestion of this study by identifying usable admission patterns and student admission trend. In particular, this paper resolved following key question, which are always asked by the senior management: 1) if there is any internal competition and how severe the competition is. 2) If there is any programme that can be utilized as strategic recruitment? I.e. if there is any programme that can bring us more students in future; and 3 ) the general student admission trend of the 8 years.

With this study, management can better understand where our sources of applicants come from. Perhaps new insight can be drawn and new strategy can be defined to recruit more quality students which are also aligned with our strategic move to transform our students. The methods used in this paper can also be easily applied in other University for analyzing the admission issues, and can demonstrate to management how operation data can be utilized to form valuable insights and significant improvement can then be made based on these identified facts.

\section{REFERENCES}

[1] K. Zumwalt, \& Craig, E., "Who is teaching? Does it matter? In M. Cochran-Smith, S. Feiman-Nemser, D. J. McIntyre, \& K. E. Demers (Eds.),", Handbook of research on teacher education: Enduring questions in changing contexts, pp. 404-423, 2008.

[2] C. E. Casey, \& Childs, R. A., "Teacher education program admission criteria and what beginning teachers need to know to be successful teachers," Canadian Journal of Educational Administration and Policy, vol. 67,, pp. 1-24, 2007.

[3] T. Falkenberg, "ADMISSION TO TEACHER EDUCATION PROGRAMS: THE PROBLEM AND TWO APPROACHES TO ADDRESSING IT " Canadian Journal of Educational Administration and Policy, no. 107, 2010.

[4] E. C. Dianne Thomson, Amanda K. Ferguson., "A Role For Research In Initial Teacher Education Admissions: A Case Study From One Canadian University," Canadian Journal of Educational Administration and Policy, no. 121, pp. 1-23, 2011.

[5] B. M. Jones, "Rejecting Admission Offers to a Selective Math and Science School," Journal for the Education of the Gifted, vol. 37, pp. 269-290, 2014.

[6] J. L. Nealon, "College and university responsiveness to students -as -customers: The reorganization of service delivery in the enrollment service arena," Higher Education Managment, University of Pennsylvania, 2005.

[7] E. N. Narjaikaew Pattawan, Arayathanitkul Kwan and Cowie Bronwen, "MAGNETISM TEACHING SEQUENCES BASED ON AN INDUCTIVE 
APPROACH FOR FIRST-YEAR THAI UNIVERSITY SCIENCE STUDENTS," International Journal of Science \& Mathematics Education, vol. 8, no. 5, pp. 891-910, 2010.

[8] J. Gaubatz, "Evaluation of a Secondary School Science Program Inversion: Moving from a Traditional to a Modified-PCB Sequence.," Science Educator, vol. 22 no. 1, pp. 19-25, 2013.

[9] J. Draper, "Choosing teaching in Hong Kong: A strategy to survive the financial crisis?," Educational Research, vol. 54, no. 2, pp. 199-211, 2012.

[10] G. Kwok Chan Lai, David, "Alternate Routes in Initial Teacher Education: A Critical Review of the Research and Policy Implications for Hong Kong," Journal of Education for Teaching, vol. 34, no. 4, pp. 261-275, 2008.

[11] R. A. Ramakrishnan Srikant, "Mining Sequential Patterns: Generalization and Performance Improvements," in Proceedings of the 5th International Conference on Extending Database Technology: Advances in Database Technology, 1996, pp. 3-17.

[12] T. E. Bell, and T. A. Thayer, "Software requirements: Are they really a problem?."

[13] J.-Y. Pan, "A resilience-based and meaning-oriented model of acculturation: A sample of mainland Chinese postgraduate students in Hong Kong," International Journal of Intercultural Relations, vol. 35, no. 5, pp. 592603, 2011.

[14] W. C. Wong, Li, M. K., Chan, W. Y. V., Choi, Y. Y., Fong, C. H. S., Lam, K. W. K., Sham, W. C., So, P. P., Wong, K., Yeung, K. H. and Yeung, T. Y., "A cross-sectional study of the beliefs and attitudes towards menstruation of Chinese undergraduate males and females in Hong Kong.," Journal of Clinical Nursing, vol. 22, no. 23-24, pp. 33203327, 2013.

[15] S. W. Ng, "The Challenges of Attracting Asian Students to Study Higher Education in Hong Kong.," Higher Education, vol. 66, no. 3, pp. 272-292, 2012.

[16] Y. K. CHAN, "Learning approaches and academic achievement in full-time and part-time sub-degree Hong Kong Chinese students.," International Journal of Continuing Education \& Lifelong Learning, vol. 6, no. 2, pp. 75-86, 2014.

[17] Y. L. Ha, "Who's the Teacher? Who's the Learner? Professional Growth and Development of a Novice Teacher in Hong Kong.," Childhood Education, vol. 90, no. 1, pp. 43-53, 2014.

[18] A. P. C. Lai, Gibson, P.,Muthaly, S, "Becoming an education provider of choice in Hong Kong: An inquiry into student decision making," International Journal of Educational Management, vol. 28, no. 5, pp. 590-609, 2014.

[19] S. S. Pun, "The politics of hope and cynicism in the realization of the vision of the 334 education reform in Hong Kong," Asia Pacific Education Review, vol. 14, no. 1, pp. 55-65, 2013.

[20] S. K. F. H. Hoi Yan Cheung, "Competencies and Characteristics for Teaching Gifted Students: A Comparative Study of Beijing and Hong Kong Teachers," Gifted Child Quarterly, vol. 55, no. 2, pp. 139-148, 2011.

Authors' Profiles

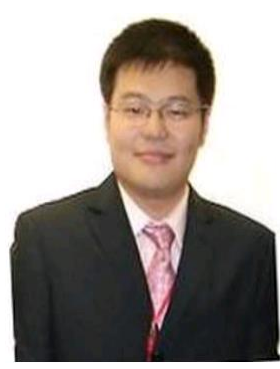

Mr. Qingyun Li received the B.Sc. and M.Sc degree in 2003 and 2006 from Northeastern University, Shenyang, and P.R. China. He is currently pursuing the Ph.D. degree with The Hong Kong Polytechnic University. $\mathrm{He}$ is also currently working as Computer Officer with The Hong Kong Institute of Education. His research interest focuses on pattern recognition, sequential pattern mining, context mining and big data visualization.

POSTGRADUATE PROGRAMMES IN THE FOLLOWING TABLES ARE THE FOCUS OF THE ANALYSIS.

\begin{tabular}{|c|c|c|c|c|c|}
\hline & & & & & Programme Code \\
\hline & & & & Full-time & Part-time \\
\hline \multicolumn{6}{|c|}{ Research Postgraduate Programmes } \\
\hline 1 & GS & PHD & Doctor of Philosophy & $\begin{array}{l}\text { A3D054/ } \\
\text { A4D054 } \\
\end{array}$ & \\
\hline 2 & GS & MPHIL & Master of Philosophy & & A2M053 \\
\hline \multicolumn{6}{|c|}{ Taught Postgraduate Programme } \\
\hline 3 & GS & EDD & Doctor of Education & A3D045 & C4D001 \\
\hline 4 & GS & MED & Master of Education & A1M043 & C2M001 \\
\hline 5 & FEHD & MA(EC) & Master of Arts in Educational Counseling & & C2M013 \\
\hline 6 & FEHD & MARE & Master of Arts in Religion in Education & $\mathrm{C} 2 \mathrm{M} 015$ & $\mathrm{C} 2 \mathrm{M} 015$ \\
\hline 7 & FEHD & IEMA & $\begin{array}{c}\text { International Executive Master of Arts in Educational Leadership and } \\
\text { Change }\end{array}$ & & $\mathrm{C} 2 \mathrm{M} 004$ \\
\hline 8 & FEHD & MSc(ESLPLD) & $\begin{array}{c}\text { Master of Science in Educational Speech-Language Pathology and } \\
\text { Learning Disabilities }\end{array}$ & A1M080 & \\
\hline 9 & FEHD & PGPSCS & Postgraduate Diploma in Psychology (Schools and Community Settings) & A1P017 & C2P047 \\
\hline 10 & FHM & MACSLE & Master of Arts in Chinese Studies (Language Education) & A1M052 & $\mathrm{C} 2 \mathrm{M} 002$ \\
\hline 11 & FHM & MAELACS & Master of Arts in Educational Linguistics and Communication Sciences & A1M060 & C2M012 \\
\hline 12 & FHM & MATCIL & Master of Arts in Teaching Chinese as an International Language & A1M046 & \\
\hline 13 & FHM & MATESOL & Master of Arts in Teaching English to Speakers of Other Languages & A1M057 & $\mathrm{C} 2 \mathrm{M} 010$ \\
\hline
\end{tabular}

